\title{
Genetic engineering: An additional tool for plant improvement
}

\author{
S. Mohan Jain, Christian Oker-Blom, Eua Pehu and R.J. Newton
}

Jain, S.M., Oker-Blom, C., Pehu, E. \& Newton, R.J. Genetic engineering: An addi-
tional tool for plant improvement. Agric. Sci. Finl. 1: 323-338. (Univ. Helsinki,
Dept. Plant Production, SF-00710, Helsinki, Finland, Abo Akademi University, Dept.
Biochemistry \& Pharmacy, SF-20520, Turku, Finland and Texas A \& M Univ., Dept.
Forest Sci., College Station, Texas, USA.)

Advances in gene transfer technologies have enabled the production of both monocot and dicot transgenic plants. With the biolistic method, genes can be transferred in recalcitrant crop plants and forest trees, independent of their genotype. Inexpensive methods for both stable and transient gene transfers - ultrasonication, direct DNA insertion during imbibition using somatic embryos, and silicon carbide fibres - have been developed. The frequency of Agrobacterium-mediated transformation rates of cloned genes can be enhanced in plant cells. The analysis of molecular markers (RFLPs, RAPDs, DNA fingerprints) can accomplish the characterization, gene mapping and identification and certification and patent protection of cultivars. With PCR, selective amplification of a specific DNA segment from a small amount of an organism's total DNA can be used to identify transgenic cultivars. The expression of a target gene can be inhibited with antisense RNA. So far, a limited number of genes have been identified and cloned with genetic engineering. With specific gene transfers, many goals such as biological control of insect pests and fungi, male sterility, virus resistance, improving seed protein, and production of transgenic plants as "bioreactors" can be accomplished. T-DNA mutagenesis may lead to learning more about the genetic control of plant development and morphogenesis, and isolation of useful mutants. Before genetic engineering becomes a reliable tool of plant breeding, more attention is needed to explore: (a) new plant genetic resources in order to identify and clone new genes, (b) fate of selective and scorable marker genes, and (c) field evaluation of transgenes in transgenic plants.

Keywords: biolistic, electroporation, PCR, RFLP, RAPD, liposomes, Agrobacterium tumefaciens, antisense RNA, transgenic plants as bioreactors, biocontrol, DNA fingerprinting, T-DNA mutagenesis

\section{Introduction}

Crop plants have been improved with traditional plant breeding methods utilizing natural variation within different genetic resources. The output of world food production has increased considerably with improved agronomic practices. However, a constant pressure still remains on plant breeders to increase crop production due to ever increasing growth of human population.

Rapid advances have taken place in plant tissue culture and genetic engineering. With tissue culture we can select and produce plants with desirable traits such as high yield and herbicide and environmental stress resistance, both within a short period of time (JAIN and PEHU 1992). Successful genetic 
engineering of plants requires: (a) gene isolation and identification, (b) insertion of isolated genes with selective marker genes into a cloning vector, (c) transformation of recipient plant cells, (d) regeneration of transgenic plants, and (e) testing inheritance and expression of the gene in transgenic plants. Since gene transfer technologies and selective and scorable marker genes are available, genetic transformation of monocot and dicot plants can be readily accomplished. Currently, the greatest constraint of genetic engineering on plant improvement is the availability of only a limited number of cloned genes for use in the improvement of the economic biological importance of crop plants. Until now, only a few genes which are of use in crop improvement have been cloned, characterized and transferred in plant cells. Restriction fragment length polymorphism (RFLP) and random amplified polymorphic DNA (RAPD) techniques have become widely used for gene mapping and identification of agronomically-important crops (ELDREDGE et al. 1992, HubBARD et al. 1992, TANKSLEY et al. 1989). Furthermore, more useful isolated genes and their stable expression in transgenic plants will be needed for continued crop improvement.

In Finland, most of the crop production problems are related to the environmental stress - viruses, insect pests, fungal diseses, cold, day length, rainfall and drought. The environmental pollution is causing greenhouse effect and may have an adverse impact on global agriculture, including Finland. These problems may be addressed with genetic engineering.

\section{Gene transfer technologies}

Progress in gene transfer technologies has revolutionized the introduction of exogenous DNA into recalcitrant plants such as maize, cotton, rice, soybean and forest trees to produce transgenic plants. CHRISTOU et al. (1991) suggested certain criteria for the development of a practical gene transformation system for any crop: (1) a cultivar or genotype-independent transformation system, (2) the recovery of large number of transgenic plants for the evaluation of gene expression, and (3) minimizing tissue culture manipulations in order to avoid somaclonal variations.

Most gene transfers have been accomplished with Agrobacterium tumefaciens and A. rhizogenes with a wide range of dicotylednous plants (FRALEY et al. 1986). Until recently, the monocotylednous and particularly graminaceous crop species have been recalcitrant to gene transfer with $A$. tumefaciens. The demonstration of Agrobacterium TDNA (AT-DNA) integration into genomic DNA of Asparagus officinalis (BYTEBIER et al. 1987), Dioscorea bulbifera (SCHAFER et al. 1987), Oryza sativa (RAINERI et al. 1990), Triticum aestivum (MOONEY et al. 1991) and Zea mays (Gould et al. 1991) showed that monocot species could be transformed by Agrobacterium. The agroinfection (Agrobacterium- mediated transfer [A-MT] of viral sequences to plant cells) method was used to incorporate the cauliflower mosaic virus into the ATDNA and to be inoculated onto Brassica rapa (GrIMSLEY et al. 1986). The development of viral symptoms in inoculated plants implied the presence of AT-DNA in cell nuclei based on replication of the virus in the host nucleus. The competence of susceptibility of plant cells to agroinfection is dependent upon meristem tissue of the shoot apex (GRIMSLEY et al. 1988) and the early developmental stages of immature embryos (SCHLÄPPI and HoHN 1992). Recently, A-MT has been used to introduce foreign genes into higher plant chloroplasts by site-specific homologous recombinations (VENKATESWARLU and NAZAR 1991).

Alternative methods such as electroporation, biolistics, liposomes etc. for genetic transformation have been developed (JAIN et al. 1988, POTRYKUS 1991). Electroporation is used for optimizing gene transfer efficiency and transient gene expression in plant protoplasts (FromM et al. 1985, 1986) and for the uptake of various dyes and exogenous DNA in germinating pollen grains (MISHRA et al. 1987, ABDUL-BAKI et al. 1990). Since pollen is the natural carrier of DNA to the ovary in flower fertilization, transgenic pollen grains may be used to fertilize 
ovaries in vitro and transgenic seeds can be obtained.

The biolistic delivery system allows the direct delivery of DNA into intact cells and tissues. In this method, DNA coated microprojectiles are accelerated to velocities that permit their penetration of cell walls and membranes without causing lethal damage to the tissues (SANFORD 1990, KLEIN et al. 1992). This system has facilitated gene transfer into many plant tissues (KLEIN et al. 1988), organelles (Boynton et al. 1988, Blowers et al. 1989), cell suspensions of Hordeum vulgare (MENDEL et al. 1989), embryogenic cell suspensions of Triticum aestivum (VASIL et al. 1991) and Picea abies (NEWTON et al. 1992), anther cultures (CREISSEN et al. 1990), and immature zygotic embryos (KARTHA et al. 1989) of $H$. vulgare, and Oryza sativa (CHRISTOU et al. 1991), higher plant chloroplasts (DANIEL et al. 1990, 1991, YE et al. 1990, SvAB et al. 1990), stem sections of cranberry (SERRES et al. 1992) and intact germinating embryos (LoNSDALE et al. 1990). In addition to $P$. abies (NEWTON et al. 1992) transient expression of the GUS (B-glucuronidase) gene with biolistic technique has also been demonstrated in tissues of forest trees such as $P$. mariana (DuCHENCE and Charest 1991), Pinus taeda (SтомP et al. 1991) and Liriodendron tulipifera (WILDE et al. 1992). SANFORD (1992) has suggested that the critical parameters for the minimum variation and maximum efficiency of biolistic transformation, which are: (a) microprojectile parameters particle size, coating procedure, dry-down in the absence of free water and with low humidity; (b) biolistics parameters- pressure (velocity), distance to target, and trauma control; and (c) biological parameters- choice of target tissue, amount of exposed cell surface area, cellular state (i.e. healthy and mitotically active), and osmotic conditioning (reducing cellular turgor). SAUTTER et al. (1991) constructed a novel microprojectile accelerating system for efficient gene transfer into cells in situ that avoids binding of DNA to microprojectiles and keeps the DNA in solution.

JAIN (1986) has suggested the use of an ultraviolet laser beam for gene transfer through the drill- ing of a hole in plant cell wall and injecting isolated foreign DNA into the cell. The laser beam technique can also be used in chromosome surgery for partial genome transfer. WEBER et al. (1989) demonstrated the incorporation of DNA into isolated chloroplasts of B. napus with UV-laser microbeam.

Liposomes (artificial lipid vesicles) have been used to deliver biologically active molecules into both animal and plant cells (JAIN et al. 1988, GAD et al. 1990, CABOCHE 1990). GAD et al. (1990) suggested several advantages of using liposomes as vectors for gene delivery into plant cells: (1) enhanced delivery of encapsulated DNA by membrane fusion, (2) prevention of damage of nucleic acids from nuclease activitiy, (3) targeting to specific cells, (4) delivery of intact small organelles, and (5) delivery into a variety of cell types by entry through plasmodesmata. The positively charged liposomes have been shown to deliver DNA into germinating pea pollen grains (АноКAS 1987). The negatively charged liposomes have been demonstrated to adhere strongly to watermelon pollen grains and tubes and to fuse with pollen tube membrane (GAD et al. 1988). WANG et al. (1986) showed that $\mathrm{pH}$-sensitive liposomes dramatically release their contents into cytoplasm of plant protoplasts at a pH less than or equal to 6.0. Recently, ZHU et al. (1990) transformed tobacco protoplasts with $\mathrm{pH}$-sensitive liposomes and regenerated transgenic plants. Inspite of several advantages of liposome-mediated gene transfer, still the main problem remains its low frequency of transformation rate of plant cells.

Another method sonication, has resulted in the transient expression of the CAT gene in protoplasts of Nicotiana tabacum and Beta vulgaris (JOERSBO and BRUNSTEDT 1990) and in GUS expression in leaf segments and regeneration of transgenic plants of $N$. tabacum (ZHANG et al. 1991). Another simple strategy for gene transfer is the insertion of exogenous DNA into embryo plant cells during imbibition using somatic embryos of Medicago sativa (Senaratna et al. 1991). This method has been used to produce both transient and stable trans- 
formations in M. sativa. Exogenous DNA has also been delivered into $Z$. mays and $N$. tabacum suspension culture cells with silicon carbide fibers to introduce GUS gene (KAEPPLER et al. 1990). These techniques are inexpensive and relatively simple to use.

\section{Selectable marker genes}

The introduction of new genes into crop plants always requires the introduction of selection marker gene (s). These are needed for the testing of gene expression and testing for favourable growth of transformed cells. Chimeric genes consisting of plant promoter sequences and bacterial antibioticresistance gene have mostly been used in the selection of transformed plant cells. The most commonly used selectable marker has been the neomycin phosphotransferase type II (NPT II) enzyme, originated from transposon Tn5. This enzyme detoxifies aminoglycoside compounds such as kanamycin (Kan) and G418 (SANGWAN and SANGWANNorREEL 1990). Among the visually scorable markers commonly used are the bacterial GUS and firefly luciferase genes (JAIN et al. 1988, SANGWAN and Sangwan-Norreel 1990). Similarly, other selectable markers that have been used are: bleomycin resistance; chloramphenicol acetyltransferase (CAT) which confers resistance-chloramphenicol; dehydrofolate reductase (DHFR)-methotrexate resistance; streptomycin phosphotransferase-streptomycin resistance; phosphinothricin acetyltransferase (bar gene)- phosphinothricin resistance; EPSP synthase (5, enolpruvylshikimate3-phosphate synthase) (aro A gene)- glyphosate resistance; and gentamycin-3-N-acetyltransferasegentamycin resistance (SANGWAN and SARGWANNorreel 1990, UChimiYa et al. 1989). Walters et al. (1992) has used the selectable marker hygromycin phosphotransferase (HPT) gene for recovering transformed Zea mays. Most of the selective and scorable marker genes incorporate in plant chromosomes and rarely in organelles such as chloroplasts or mitochondria. However, DE BLOCK et al. (1985) demonstrated the insertion of the CAT gene into the chloroplast genome.

The selectable and scorable marker genes and their encoded proteins remain in the transgenic plants and their food products. In the future, they will become integral components of crops and our diets. The major concern of regulatory committees and the individual consumers worldwide is the food and environmental safety of these markers. FLAVELL et al. (1992) has concluded that the NPT II marker gene and its product pose no risk to the mankind or to the environment. However, a caseby-case examination of each marker gene will be necessary before their broad use in agriculture will be permitted.

\section{Enhancement of genetic transformation rates}

The efficient transfer of cloned genes into plants is a prerequisite to the understanding of the regulation of gene expression. The mechanisms that govern uptake and integration of foreign DNA into plant cells are unknown. GiETL et al. (1987) suggested that single-stranded-DNA-binding proteins are involved in the production of T-DNA intermediates or that they have a carrier or protective function during T-DNA transfer with Agrobacterium. The direct microinjection of exogenous DNA into the nucleus of plant cells has enhanced the frequency of transformation. This has led to the assumption that the nuclear membrane might be a substantial barrier for the import and incorporation of foreign DNA in plant cells (MEYER et al. 1985). Genetic transformation rates can also be affected by physical and chemical parameters, the type and variety of experimental plant species, and the efficiency of integration of heterologous plasmid DNA via illegitimate recombination (KÖHLER et al. 1990). There is no clear correlation exists between speed of initiation of cell division and the rate of transformation (TYAGI et al. 1989).

In A-MT, the "vir" (virulence) region of the $\mathrm{Ti}$ plasmid is essential for T-DNA transfer, and it is induced by specific wound substances from plants (SCHÄFER et al. 1987). The frequency of A-MT can 
be increased with acetosyringone (naturally occurring wound response phenolics, which activates the "vir" region in A. tumefaciens) in Arabidopsis (Sheikholeslam and Weeks 1987) and Atropa belladona (MATHEws et al. 1990). In Solanum tuberosum, addition of silver thiosulphate along with acetosyringone improved the transformation efficiency (Higgins et al. 1992). RoDENBERG et al (1989) reported several-fold higher stable transformants with single-stranded DNA rather than the number obtained with the corresponding doublestranded DNA, suggesting that it might be singlestranded DNA that is transferred from Agrobacterium to plant cells. Irradiation of $B$. nigra, N. tabacum, Petunia hybrida and Vigna aconitifolia protoplasts treated with plasmid-DNA and PEG enhanced transformation rates 6-7 folds (KöHLER et al. 1989, 1990). The increased integration rates of plasmid sequences into plant genome may in part be governed by DNA repair mechanisms in transformed colonies, derived from irradiated protoplasts.

Bombardment of plant tissues with microprojectiles prior to Agrobacterium-mediated transformation resulted in 100 times more transformants with tobacco leaves than when similar leaves were subjected to the standard particle gun transformation protocol (BIDNEY et al. 1992). Similarly, bombardment of sunflower apical meristems with microprojectiles prior to Agrobacterium treatment produced more cell transformants than Agrobacterium alone (BIDNEY et al. 1992). Bombardment of target tissue prior to the Agrobacterium-mediated transformation generates microwounds in the tissue and results in enhanced transformation frequency.

An increase in the transient gene expression has also been demonstrated by: (a) exon 1 and intron 1 of the shrunken 1 gene in $H$. vulgare, $Z$. mays and O. sativa protoplasts (MAAS et al. 1991); (b) treatment with cell wall inhibitor, 2,6-dichlorobenzonitirile (DB) in N. tabacum and B. napus (CHAPEL and Glimelius 1990, BinNS 1991); (c) pretreating $P$. abies embryogenic cell cultures with abscisic acid (ABA) for 3 days before biolistic bombardment (NEWTON et al. 1992); and (d) single-stranded
DNA as a vehicle for transformation (RODENBERG et al. 1989).

\section{T-DNA mutagenesis}

The Agrobacterium-mediated transformation involves the stable integration of Agrobacterium T-DNA into DNA of plant chromosomes. The integration of T-DNA within the active endogenous plant gene will often inactivate that gene which may in turn cause phenotypic mutations. The site of insertion in a phenotypic mutant can be mapped genetically (using markers contained within the T-DNA) and the sequences for the inactivated endogenous gene isolated by virtue of their proximity to the inserted T-DNA can be determined. Hopefully, the function for the endog-enous gene can also be ascribed (KNIGHT 1992). VAN LuSEBETTENS (1991) reported the genetic mapping of a gene involved in leaf morphology of $A$. thaliana. With a similar approach, KOMARI (1990) demonstrated phenotypically the production of abnormal tobacco plants with double flowers, wavy stems and bent leaf-edges. Results such as these may eventually provide information on genetic control of plant development and morphogenesis.

\section{Technologies for gene identification}

\section{Restriction fragment length polymorphism (RFLP)}

In the past, plant breeders have developed new cultivars by selecting plants with desirable phenotypes without the use of molecular markers and without the understanding of how genes control characteristics of economic interest. Now, to aid the breeders, RFLP linkage maps have been constructed for many major crop plants such as Lycopersicon esculentum (BERNATZKY and TANKSLEY 1986), Solanum tuberosum (BONIERABLE et al. 1988, JACOBS et al. 1990), Secale cereale (WANG et al. 1991), Z. mays (BURR et al. 1988), Lactuca sativa (LANDRY et al. 1987), T. aestivum (KAM-MorGAN and GILL 1989), and $O$. sativa (McCouCH et al. 1988). These RFLP 
linkage maps and markers are helpful for selecting and locating desirable genes such as disease resistance (SARFATti et al. 1991, Bentolila et al. 1991; Yu et al. 1991, PARAn et al. 1991, Melchinger 1990), root knot nematode resistance (KLEINLANKHORST et al. 1991, MESSEguer et al. 1991, Powell et al. 1991), insect resistance (NIENHUIS et al. 1987), soluble solids content (OSBORN et al. 1987), characterization of somaclonal variation (MULLER et al. 1990), molecular genetic variability (KoCHERT et al. 1991), determination of quantitative trait loci underlying tolerance to lowphosphorous stress (REITER et al. 1991), cultivar identification, certification and patent protection (HUBBARD et al. 1992) and applications to forest genetics and tree improvement (NEALE and Williams 1991). Aly et al. (1992) demonstrated the genetic origin of walnut somatic embryos using RFLP and isozymes analysis. So far, RFLP maps have been constructed for mostly diploid crop plant species. RFLP mapping of polyploids such as sugarcane, Fragaria x ananassa etc. have lagged behind. Wu et al. (1992) proposed a general method for mapping polyploids based on the segregation (in 1:1 ratio) of single-dose restriction fragments (SDRFS) in gametes of heterozygous plants.

\section{Random amplified polymorphic DNA (RAPD)}

Williams et al. (1990) has described a new technique random amplified polymorphic DNA (RAPD), which can be used for genetic mapping and gene identification. Genetic maps, consisting of RAPD markers can be obtained more efficiently and with greater density than with RFLP or targeted PCR-based methods. Xu et al. (1992) identified somatic hybrids between Solanum tuberosum and $S$. brevidens with RAPD markers in a very short time when compared to RFLP markers. For preliminary screening of somatic hybrids, this method could detect hybridity of fusion products at either the callus level or at a juvenile stage of growth. RAPD markers have been used for mapping traits in segregating populations, disease resistance and analysis of molecular taxonomy
(RAFALSKI et al. 1991).

\section{Polymerase chain reaction (PCR)}

The polymerase chain reaction is an enzymatic method for generating millions of identical copies of relatively short DNA molecule in a few hours without the need for conventional cloning techniques. Since its introduction by SAIKI et al. (1985), amplification of DNA by PCR has been used for many applications in biology and medicine. With PCR, specific sequences have been detected in transformed plant tissues of $N$. tabacum, N. rustica (HAMiLl et al. 1990 b, 1991) and $Z$. mays (Gould et al. 1991). WiLliams et al. (1990) generated RAPDs with PCR-amplified DNA sequences in total genomic DNA. The characterization of different allelic forms and the detailed study of genetic polymorphisms can be done by direct cloning of genomic sequences amplified by PCR. The use of PCR revealed inter- and intra-specific genetic polymorphism in $T$. aestivum (D'Ovidıo et al. 1990), cloning and nucleotide sequence of a PCR amplified DNA fragment corresponding to a gamma gliadin gene from Triticum turgidum (D’Ovidio et al. 1991), genome-specific markers in Brassica (Quiros et al. 1991), nucleotide sequence of PCR-amplified osmotin cDNA from saltadapted Nicotiana cell suspension cultures (KUMAR and SPENCER 1992), DNA markers linked to nematode resistance in Beta vulgaris (JUNG et al. 1992) and detection of transcripts homologous to the selfincompatibility gene in Brassica anthers (GUILLUY et al. 1991). Furthermore, PCR-amplification, combined with custom-synthesized oligodeoxy- ribonucleotide (oligo) primers, can be used to ease subsequent genetic engineering steps such as translational fusions (SLightom 1991). The gene (cp) encoding the coat protein of cucumber mosaic virus was PCR-engineered for expression in Nicotiana (NAMBA et al. 1991). With inverse PCR, T-DNA copy number have been estimated in young transgenic Nicotiana plants within 10 weeks of transformation with A. tumefaciens (DoEs et al. 1991). Recently, JongediJK et al. (1992) used PCR and 
inverse PCR-based identification of transgenic $S$. tuberosum plants from original cultivars. Several recent articles on PCR have been published (Krawetz 1989, Erlich et al. 1991, GibBS 1991, RosentHal 1992).

\section{DNA fingerprint analysis}

In genomic DNA of various species, minisatellite and microsatellite DNA sequences have been found to detect several loci consisting of tandom repeats of a short nucleotide sequence (10-60 base pairs). Analysis of these sequences yields very high levels of polymorphism. This is due to tandom repeats, presumbly resulting from unequal mitotic or meiotic exchanges or by DNA slippage during replication. At a given locus, numerous alleles differing in the number of repeats, may thus occur. Probes have been found that hybridize to fragments from several variable loci simultaneously, producting an autoradiograph with a complex fragment pattern, called a DNA "fingerprint" (TzURI et al. 1991). These fragments are inherited in a Mendelian fashion, and they therefore provide a technique suitable for genetic analysis. DNA fingerprints are highly individual-specific (JEFFERY et al. 1985). They are applicable in: (a) genetic variation studies, (b) forensic and ecological studies, (c) in breeding programme and in population genetics, and (d) in the analysis and characterization of a plant genome (WEISING and KaHL 1990). TzURI et al. (1991) identified cultivars of rose, gerbera and carnation ornamental plants, and studied genetic variability in Salix (Vahala et al. 1991), Malus, Prunus, Rubus (Nүвом 1990, Nүвом et al. 1990, NyBOM and SchaAl 1990), indicating the use of DNA fingerprinting for genotype identification.

\section{Antisense RNA}

Regulation of gene expression in plant cells is helpful in the understanding the function of gene products. The expression of target genes can effectively be inhibited in a number of different organisms by antisense genes which acts by synthesizing anti- sense RNA which forms a duplex with the target mRNA. This mRNA is then either inaccessible for nuclear processing, is rapidly degraded by RNAses or is blocked for translation (van der KROL et al. 1990). ECKER and DAVIS (1986) reported that the transient expression of the CAT gene was inhibited when an antisense CAT gene was simultaneously introduced into protoplasts. A high ratio of antisense to sense RNA was necessary for effective inhibition of gene expression. ROTHSTEIN et al. (1987) observed a stable and heritable inhibition of nopaline synthase (nos) expression in Nicotiana plants transformed with sense and antisense constructs of the nos gene. While investigating the effect of nos antisense sequences from different regions of the gene on nos expression, SANDLER et al. (1988) showed that inhibition of nos expression varied with the region of nos antisense used. DELAUNEY et al. (1988) demonstrated that fusion of an antisense CAT gene to a hygromycin resistance gene inhibited CAT expression while the antisense CAT alone was ineffective. Expression of antisense RNA in transgenic plants has been effective in reducing polygalacturonase activity (SMITH et al. 1988, 1990), chalcone synthase expression for inhibiting flower pigmentation (VAN DER KROL et al. 1990), GUS (RoBERT et al. 1990), organ-specific modulation of gene expression (CANNON et al. 1990), carotenoid biosynthesis (BIRD et al. 1991), decreased ribulose-1,5-bisphosphate carboxylaseoxygenase activity in transgenic Nicotiana plants (Quick et al. 1991, STITT et al. 1991), and ethylene synthesis (HAmilton et al. 1990). Resistance to specific viruses by expression of a negative-sense coat protein gene transcript have been shown for the potato virus X (PVX) (HEMENWAY et al. 1988) or cauliflower mosaic virus (CMV) (Cuozzo et al. 1988) and the potato leafroll virus (PLRV) (KAWCHUK et al. 1991). In all cases, the protection occurred, but only at low virus inoculum levels.

\section{Transgenic plants as bioreactors}

Plants have traditionally been the source of food and raw materials for many industries. For pharma- 
ceutical industries, plant cell and callus cultures could be exploited for the production of secondary metabolites. With the advent of plant genetic engineering, plants could be used as a vehicle for the production of new compounds, and the overproduction, or conversion of compounds naturally occurring in the host plant (PEN et al. 1992). There are several reports on the expression of commercially useful heterologous proteins and peptides in plants such as Human serum albumin (HSA) protein (SiJMONS et al. 1990), alpha-amylase from B. licheniformis (PEN et al. 1992), antibiotics (HiatT et al. 1989, During et al. 1990), interferon (DEZOETEN et al. 1989) and enkephalins (VANDEKERCKHOVE et al. 1989). The success of producing proteins in plants will depend upon the expression level of the protein and the cost of production when compared with other established protocols. Alphaamylase is a bulk enzyme used for industrial applications, but not in the medical field where purity requirements are not very stringent. For such proteins, transgenic plants could be used as ideal bioreactors for mass production at low costs.

\section{Cloned genes and their expression}

Until now, only single, plant genes have been cloned, characterized and transferred into plant cells. These are herbicide resistance (COMAI et al. 1985, ShaH et al. 1986, STALKER et al. 1988; STREBER and WILLMITZER 1989, D'HALLUIN et al. 1992), isopentyl transferase (SMIGOCKI and OWENS 1988), insect resistance from $B$. thuringiensis (VAECK et al. 1987, Delannay et al. 1989, PerlaK et al. 1990, CHENG et al. 1992), insect pest resistance due to cowpea trypsin inhibitors coding for proteinase inhibitors (HILDER et al. 1987, 1989), fungal protection (LOGEMANN et al. 1992), virus coat protein (BEACHY et al. 1990, Powell et al. 1986, 1989, 1990, KawChUK et al. 1990, Kallerhoff et al. 1990, Ehlers et al. 1991, GIELEN et al. 1991), pollen development (MARIANI et al. 1990), phaseolin gene (CHEE et al. 1986, Sengupta-Gopalan et al. 1985), methionine-rich seed protein from Brazil nut (AltenBACH et al. 1992), yeast ornithine de- carboxylase gene for increasing plant secondary product nicotine (HAMILL et al. 1990 a), chalcone synthase gene (DOERNER et al. 1990) and cold resistance (KURKELA and FRANCK 1990). There is still an uphill task of identifying the sets of genes that regulate important agronomic traits in food crops such as yield, grain moisture content at harvest, tillering, and increase in number of spikelets.

Biocontrol of insect pests in plants can be accomplished with genetically engineered 'biopesticides'. Baculoviruses provide an alternative to chemicals for controlling insect pests. They can also be applied by spraying. STEWART et al. (1991) constructed a baculovirus insecticide containing an insect-specific neurotoxin from the venom of the North African (Algerian) scorpian, Androctonus australis. In a similar report, a toxin (TxP-I) gene from the female mite (Pyemotes tritici) venom which causes muscle-contractive paralysis when injected into insects. It was cloned, sequenced and expressed in baculovirus (TOMALISKI and MILLER 1991). Larvae infected with this recombinant baculovirus became paralysed during infection, thus reflecting an effective insect biocontrol method.

\section{Conclusions}

Genetic engineering has an enormous potential for plant improvement by introducing foreign genes in cells or tissues of both monocot and dicot plants. Transient and stable gene transfer in plant tissues and cells should be independent of genotype. The regulation of gene expression can be studied efficiently by enhancement of frequency gene transfer. With antisense RNA, the expression of a target gene can be inhibited such as flower pigmentation, virus resistance, carotenoid biosynthesis.

The molecular markers - RFLP's, RAPD's, DNA-fingerprints - can be of practical value to plant breeders especially in characterization for agronomic and morphological traits, certification and patent protection, and cultivar identification. Therefore, an interaction between molecular biologists and plant breeders will be desirable.

Transgenic plants may be developed to use as 
bioreactors for bulk production of commercial grade products. The biological control of insect pests and fungi need to be addressed using genetic engineering. Such results would reduce the use of chemical pesticides and fungicides. Many single plant genes have been transferred in monocot and dicot plants and yet more task of identifying genes that regulate agronomically important traits in food crops lies ahead. Genetic control of plant development and morphogenesis require attention for better plant production. The emerging new technologies may not efficiently solve all the problems. Therefore, they should be selectively used depending on the nature of the problems. More attention is needed for field evaluation of transgenes, and the fate of selective and scorable marker genes in transgenic crop plants. The major contributions of genetic engineering in crop improvement would ultimately make it a new reliable tool for plant improvement.

The agronomical problems in Finland are somewhat different than the problems in warmer climatic countries. The crop plants are mainly damaged due to environmental stress - viruses, insect pests, diseases, cold, day length, rainfall and drought - in Finland. Therefore, agriculture biotechnology research needs direction to tackle these problems and also to improve tillering, grain filling, nitrogen fixation in fodder crops, fodder quality - improving seed proteins. The global environmental pollution is causing greenhouse effect. The adaptation of crop plants to these enviornmental changes may be slow and thereby may result in crop damage and ultimately reduction in yield. Transgenic plants - resistant to environmental pollution stress - may be developed. In cereals, attention is needed: (a) to prevent dormancy breakdown due to rains which results in poor end-use quality, and (b) to study the mechanism of hull formation in naked oats. Naked oats have high feeding value.

Acknowledgements. We thank Mr. Jari Peltonen for useful discussions, Mrs. Marja-Liisa Jain and Mr. Jari Valkonen for translation work, and Dr. David Thompson (Ireland) for reading the manuscript.

\section{References}

Abdul-Baki, A.A., Saunders, J.A., Mathews, B.F. \& PITTARELLI, G.W. 1990. DNA uptake during electroporation of germinating pollen grains. Plant Sci. 70: 181-190.

AHOKAS, H. 1987. Transfection by DNA-associated liposomes evidenced at pea pollination. Hereditas 106: 129 . 138.

Altenbach, S.B., Kuo, C.C., Staraci, L.C., Pearson, K.W., Wainwright, C., Georgescu, A. \& Townsend, J. 1992. Accumulation of Brazil nut albumin in seeds of transgenic canola results in enhanced levels of seed protein methionine. Plant Mol. Biol. 18: 235-245.

Aly, M.A.M., Fjellstrom, R.G., McGranahan, G.H. \& PARFITT, D.E. 1992. Origin of walnut somatic embryos determined by RFLP and isozyme analysis. HortSci. 27: 61-63.

BeAchy, R.N., Loesch-Fries, S. \& TUMER, N.E. 1990. Coatprotein-mediated resistance against virus infection. Ann. Rev. Phytopathol. 28: 451-474

Bentolila, S., Guitton, C., Bouvet, N., Sailland, A., NyKAZA, S. \& FreysSINET, G. 1991. Identification of an RFLP marker tightly linked to the $\mathrm{Htl}$ gene in maize.
Theor. Appl. Genet. 82: 393-398.

BERNATZKY, R. \& TANKSLEY, S.D. 1986. Genetics of actin related sequences in tomato. Theor. Appl. Genet. 72: 314-321.

Bidney, D., Scelonge, C., Martich, J., Burrus, M., Sims, L. \& Huffman, G. 1992. Microprojectile bombardment of plant tissues increases transformation frequency by Agrobacterium tumefaciens. Plant Mol. Biol. 18: 301313.

BinNS, A.N. 1991. Transformation of wall deficient cultured tobacco protoplasts by Agrobacterium tumefaciens. Plant Physiol. 96: 498-506.

Bird, C.R., Ray, J.A., Fletcher, J.D., Boniwell, J.M., Bird, A.S., Teulieres, C., Blain, I., Bramley, P.M. \& SснUCH, W. 1991. Using antisense RNA to study gene function: Inhibition of carotenoid biosynthesis in transgenic tomatoes. Biotech. 9: 635-639.

Blowers, A.D., Bogorad, L., Shark, K.B. \& Sanford, J.C. 1989. Studies on Chlamydomonas chloroplast transformation: foreign DNA can be stably maintained in the chromosome. Plant Cell 1: 123-132. 
Bonierbale, M.W., Plaisted, R.L. \& Tanksley, S.D. 1988. RFLP maps based on a common set of clones reveal modes of chromosomal evolution in potato and tomato. Genetics 120: 1095-1103.

Boynton, J.E., Gillham, N.W., Harris, E.H., Hosler, J.P., JOHNSON, A.M., JONES, A.R., RANDOLPH-ANDERSON, B.L., RobertSON, D., Klein, T.M., Shark, K.B. \& SANFORD, J.C. 1988. Chloroplast transformation in Chlamydomonas with high velocity microprojectiles. Sci. 240 : 1534- 1538.

Burr, B., Burr, F.A., Thompson, K.H., Albertson, M.C. \& STUBER, C.W. 1988. Gene mapping with recombinant inbreds in maize. Genetics 118: 519-526.

Bytebier, B., Deboeck, F., Greve, H.D., Van Montagu, M., \& HeRnAlsteEnS, J.P. 1987. T-DNA organization in tumor cultures and transgenic plants of monocotyledon Asparagus officinalis. Proc. Natl. Acad. Sci. USA. 84: 5345-5349.

CABOCHE, M. 1990. Liposome-mediated transfer of nucleic acids in plant protoplasts. Physiol. Plant. 79: 173-176.

Cannon, M., Platz, J., O'Leary, M., Sookdeo, C. \& CanNON, F. 1990. Organ-specific modulation of gene expression in transgenic plants using antisense RNA. Plant Mol. Biol. 15: 39-47.

Chapel, M. \& Glimelius, K. 1990. Temporary inhibition of cell wall synthesis improves the transient expression of the GUS gene in Brassica napus mesophyll protoplasts. Plant Cell Rept. 9: 105-108.

Chee, P.P., Klassy, R.C. \& Slightom, J.L. 1986. Expression of a bean storage protein 'phaseolin minigene' in foreign plant tissues. Gene 41: 47-57.

Cheng, J., Bolyard, M.G., Saxena, R.C. \& Sticklen, M.B. 1992. Production of insect resistant potato by genetic transformation with a \&-endotoxin gene from Bacillus thuringiensis var. kurstaki. Plant Sci. 81: 83-91.

Christou, P., Ford, T.L. \& Kofron, M. 1991. Production of transgenic rice (Oryza sativa L.) plants from agronomically important indica and japonica varieties via electric discharge particle acceleration of exogenous DNA into immature zygotic embryos. Biotech. 9: 957962.

Comai, L., Facciotti, D., Hiatt, W.R., Thompson, G., Rose, R.E. \& STALKER, D.M. 1985. Expression in plants of a mutant aro A gene from Salmonella typhimurium confers tolerance to glyphosate. Nature 317: 741-744.

Creissen, G., Smith, C., Francis, R., Reynolds, H. \& MulLINEAUX, P. 1990. Agrobacterium- and microprojectilemediated viral DNA delivery into barley microsporederived cultures. Plant Cell Rept. 8: 680-683.

Cuozzo, M., O'Connell, K.M., Kaniewski, W., Fang, R.X., CHUA, N.H. \& TUMER, N.E. 1988. Viral protection in transgenic tobacco plants expressing the cucumber mosaic virus coat protein or its antisense RNA. Biotech. 6: 549-557.

Daniell, H., Krishnan, M. \& McFadden, B.F. 1991. Transient expression of B-glucuronidase in different cel- lular compartments following biolistic delivery of foreign DNA into wheat leaves and calli. Plant Cell Rept. 9: 615-619.

Daniell, H., Vivekananda, J., Nielsen, B.L., Ye, G.N., TeWARI, K.K. \& SANFORD, J.C. 1990. Transient foreign gene expression in chloroplasts of cultured tobacco cells after biolistic delivery of chloroplast vectors. Proc. Natl. Acad. Sci. USA. 87: 88-92.

De Block, M., Schell, J. \& Van Montagu, M. 1985. Chloroplast transformation by Agrobacterium tumefaciens. EMBO J. 4: 1367-1372.

Delannay, X., LaVallee, Proksch, R.K., Fuchs, R.L., Sims, S.R., GreenPlate, J.T., Marrone, P.G., Dodson, R.B., Augustine, J.J., LAYTON, J.G. \& FisChHOFF. 1989. Field performance of transgenic tomato plants expressing the Bacillus thuringiensis var. kurstaki insect control protein. Biotech. 1: 1265-1269.

Delauney, A.J., Tabaeizadeh, Z. \& Verma, D.P.S. 1988. A stable bifunctional antisense transcript inhibiting gene expression in transgenic plants. Proc. Natl. Acad. Sci. USA. 85 : 4300-4304.

DeZoeten, G.A., Penswick, J.R., Horisberger, M.A., Aht, M.A., Schultze, M. \& Hohn, T. 1989. The expression, localization and effect of a human interferon in plants. Virology 172: 213-222.

D'Halluin, K., Bossut, M., Bonne, E., Mazur, B., LeeMANS, J. \& Botterman, J. 1992. Transformation of sugarbeet (Beta vulgaris L.) and evaluation of herbicide resistance in transgenic plants. Biotech. 10: 309-314.

Doerner, P.W., Stermer, B., Schmid, J., Dixon, R.A. \& LAMB, C.J. 1990. Plant defense gene promoter-reporter gene fusions in transgenic plants: tools for identification of novel inducers. Biotech. 8: 845-848.

DOES, M.P., DEKKER, B.M.M., DE GROOT, M.J.A. \& OFFrINGA, R. 1991. A quick method to estimate the TDNA copy number in transgenic plants at an early stage after transformation, using inverse PCR. Plant Mol. Biol. 17: 151-153.

D’Ovidio, R., Tanzarella, O.A. \& Porceddu, E. 1990. Rapid and efficient detection of genetic polymorphism in wheat through amplification by polymerase chain reaction. Plant Mol. Biol. 15: 169-171.

-, Tanzarella, O.A. \& Porceddu, E. 1991. Cloning and sequencing of a PCR amplified gamma-gliadin gene from durum wheat (Triticum turgidum L.) Thell. conv. durum (Desf.) MK.). Plant Sci. 75: 229-236.

DuChense, L.C. \& ChAREST, P.J. 1991. Transient expression of the B-glucuronidase gene in embryogenic callus of Picea mariana following microprojection. Plant Cell Rept. 10: 191-194.

During K., Hippe, DS., Kreuzaler, F. \& Schell, J. 1990. Synthesis and self-assembly of a functional monoclonal antibody in transgenic Nicotiana tabacum. Plant Mol. Biol. 15: 281-293.

ECKER, J.R. \& DAVIS, R.W. 1986. Inhibition of gene expression in plant cells by expression of antisense RNA. Proc. 
Natl. Acad. Sci. USA. 83: 5372-5376.

Ehlers, U., Commandeur, U., Frank, R., Landsmann, J., Koenig, R. \& Burgermeister, W. 1991. Cloning of the coat protein gene from beet nectrotic yellow vein virus and its expression in sugar beet hairy roots. Theor. Appl. Genet. 81: 777-782.

Eldredge, L., Ballard, R., Baird, W.V., AbBott, A., Morgens, P., Callahan, A., Scorza, R. \& Monet, R. 1992. Applications of RFLP analysis to genetic mapping in peaches. HortSci. 27: 160-163.

Erlich, H.A., Gelfand, D. \& SninSKy, J.J. 1991. Recent advances in the polymerase chain reaction. Sci. 252: 1643-1651

Flavell, R.B., Dart, Ed, Ruchs, R.L. \& Fraley, R.T. 1992. Selectable marker genes: Safe for plants. Biotech. 10: 141-144.

Fraley, R.T., Rogers, S.G. \& Horsch, R.B. 1986. Genetic transformation in higher plants. CRC Critical Rev. Plant Sci. 4: 1-46.

Fromm, M.E., TAYlor, L.P. \& WAlBoT, T. 1985. Expression of genes transferred into monocot and dicot plant cells by electroporation. Proc. Natl. Acad. Sci. USA. 82: 5824- 5828.

-, TAYLOR, L.P. \& WALBOT, V. 1986. Stable transformation of maize after gene transfer by electroporation. Nature 319: 791.

Gad, A.E., Rosenberg, N. \& Altman, A. 1990. Liposomemediated gene delivery into plant cells. Physiol. Plant. 79: $177-183$

—, Zeewi, B. \& Altman, A. 1988. Fusion of germinating watermelon pollen tubes with liposomes. Plant Sci. 55: 69-75.

GiBBS, R.A. 1991. Polymerase chain reaction techniques. Current Opinion in Biotech. 2: 69-75.

Gielen, J.J.L., De HaAn, P., Kool, A.J., Peters, D., van Grinsven, M.Q.J.M. \& GoldBaCh, R.W. 1991. Engineered resistance to tomato spotted wilt virus, a negativestrand RNA virus. Biotech. 9: 1363-1367.

Gietz, C., Koukolikova-Nicola, Z. \& Hohn, B. 1987. Mobilization of T-DNA from Agrobacterium to plant cells involves a protein that binds single-stranded DNA. Proc. Natl. Acad. Sci. USA. 84: 9006-9010.

Gould, J., Devey, M., Hasegawa, O., Ulian, E.C., PeterSON, G. \& SMITH, R.H. 1991. Transformation of Zea mays L. using Agrobacterium tumefaciens and the shoot apex. Plant Physiol. 95: 426-434.

Grimsley, N., Hohn, B., HoHn, T. \& Walden, R. 1986. "Agroinfection" an alternative route for viral infection of plants by using the Ti plasmid. Proc.Natl. Acad. Sci. USA. $83: 3282-3286$.

-, Ramos, C., Hein, T. \& Hohn, B. 1988. Meristematic tissues of maize plants are most susceptible to agroinfection with maize streak virus. Biotech. 6: 185-189.

Guilluy, C.M., Trick, M., HeizmanN, P. \& Dumas, C. 1991. PCR detection of transcripts homologous to the self- incompatibility gene in anthers of Brassica. Theor.
Appl. Genet. 82: 466-472.

Hamill, J.D., Robins, R.J., ParR, A.J., Evans, D.M., FURZE, J.M. \& RhODES, M.J.C. 1990 a. Over-expressing a yeast ornithine decarboxylase gene in transgenic roots of Nicotiana rustica can lead to enhanced nicotine accumulation. Plant Mol. Biol. 15: 27-38.

-, Rounsley, S., SPencer, A., Todd, G. \& Rhodes, M.J.C. $1990 \mathrm{~b}$. The use of the polymerase chain reaction to detect specific sequences in transformed plant tissues. In: Nijkamp et al. (eds.). Progess in Plant Cellular and Molecular Biology. Kluwer Acad. Pub., Dordrecht, The Netherlands, p. 183-188.

-, Rounsley, S., SPencer, A., Todd, G. \& Rhodes, M.J.C. 1991. The use of polymerase chain reaction in plant transformation studies. Plant Cell Rept. 10: 221- 224.

Hamilton, A.J., Lycett, G.W. \& Grierson, D. 1990. Antisense gene that inhibits synthesis of the hormone ethylene in transgenic plants. Nature 346: 284-287.

Hemenway, C., Fang, R.X., Kaniewski, W.K., Chu, N.H. \& TUMER, N.E. 1988. Analysis of the mechanism of protection in transgenic plants expressing the potato virus $\mathrm{X}$ coat protein or its antisense RNA. EMBO J. 7: 12731280.

Hiatt, A., Cafferkey, R. \& Bowdish, K. 1989. Production of antibodies in transgenic plants. Nature 342: 76-78.

Higgins, E.S., Hulme, J.S. \& ShieldS, R. 1992. Early events in transformation of potato by Agrobacterium tumefaciens. Plant Sci. 82: 109-118.

Hilder, V.A., Gatehouse, A.M.R., Sheerman, S., Baker, R.F. \& BOULTER, D. 1987. A novel mechanism of insect resistance engineered into tobacco. Nature 300: 160163.

—, Gatehouse, A.M.R. \& Boulter, D. 1989. Potential for exploiting plant genes to genetically engineer insect resistance, exemplified by the cowpea trypsin inhibitor gene. Pestic. Sci. 27: 165-171.

Hubbard, M., Kelly, J., Rajapakse, S., Abbott, A. \& BalLARD, R. 1992. Restriction fragment length polymorphisms in rose and their use for cultivar identification. HortSci. 27: 172-173.

Jacobs, J.J.M.R., Krens, F.A., Stiekema, W.J., VAN SPANJe, M. \& WagenVoORT, M. 1990. Restriction fragment length polymorphism in Solanum spp. for the construction of a genetic map of Solanum tuberosum L.: a preliminary study. Potato Res. 33: 171-180.

JAIN, S.M. 1986. Barley tissue culture and gene transfer. A report. State Biotechnology Laboratory, VTT, Espoo, Finland.

-, Newton, R.J. \& Tuleen, N. 1988. Tissue culture and gene transfer in barley. Current Sci. 57: 59-70.

— \& PeHU, E. 1992. The prospects of tissue culture and genetic engineering for strawberry improvement. Acta Agric. Scand., Sect. B, Soil and Plant Sci. (in press).

JefFerys, A.J., BroOKFIELD, J.F.Y. \& SemeonofF, R. 1985. Positive identification of an immigration test-case using human DNA fingerprints. Nature 327: 147-149. 
Joersbo, M. \& BRunStedT, J. 1990. Direct gene transfer to plant protoplasts by mild sonication. Plant Cell Rept. 9: 207-210.

JongediJK, E., DE Schutter, A.A.J.M., Stolte, T., VAN DEN Elzen, P.J.M. \& Cornelissen, B.J.C. 1992. Increased resistance to potato virus $\mathrm{X}$ and preservation of cultivar properties in transgenic potato under field conditions. Biotech. 10: 422-429.

Jung, C., Koсh, R., Fischer, F., Brandes, A., Wricke, G. \& HERRMANN, R.G. 1992. DNA markers closely linked to nematode resistance genes in sugarbeet (Beta vulgaris L.) mapped using chromosome additions and translocations originating from wild beets of the procumbentes section. Mol. Gen. Genet. 232: 271-278.

Kaeppler, H.F., Gu, W., Somers, D.A., Rines, H.W. \& COCKBURN, A.F. 1990. Silicon carbide fiber-mediated DNA delivery into plant cells. Plant Cell Rept. 9: 415418.

Kallerhoff, J., Perez, P., BouzoubaA, S., Tahar, S.B. \& PERRET, J. 1990. Beet necrotic yellow vein virus coat protein-mediated protection in sugarbeet (Beta vulgaris L.) protoplasts. Plant Cell Rept. 9: 224-228.

Kam-Morgan, L.N.W. \& GiLl, B.S. 1989. DNA restriction fragment length polymorphisms: a strategy for genetic mapping of D genome wheat. Genome 32: 724-732.

Kartha, K.K., Chibbar, R.N., Georges, F., Leung, B., Caswell, K., Kendall, E. \& Qureshi, J. 1989. Transient expression of chloramphenicol acetyltransferase CAT in barley cell cultures and immature embryos through microprojectile bombardment. Plant Cell Rept. 8: 429-439.

KawchuK, L.M., Martin, R.R. \& McPherson, J. 1990. Resistance in transgenic potato expressing the potato leafroll virus coat protein gene. Mol. Plant-Micro, Interac. 3: 301-307.

-, MARTIN, R.R. \& MCPherson, J. 1991. Sense and antisense RNA-mediated resistance to potato leafroll virus in Russet Burbank potato plants. Mol. Plant-Micro. Interac. 4: 247-253.

Klein, T.M., Harper, E.C., Svab, Z., Sanford, J.C., Fromm, M.E. \& MALIGA, P. 1988. Stable genetic transformation of intact cells by the particle bombardment process. Proc. Natl. Acad. Sci. USA. 85: 8502-8505.

-, ARENTZEN, R., Lewis, P.A. \& FitzPATRICK-McElligotT, S. 1992. Transformation of microbes, plants and animals by particle bombardment. Biotech. 10: 286-291.

Klein-Lankhorst, R., Rietveld, P., Machiels, B., VerKerk, R., Weide, R., Gebhardt, C., KoOrnnef, M. \& ZABEL, P. 1991. RFLP markers linked to the root knot nematode resistance gene $\mathrm{Mi}$ in tomato. Theor. Appl. Genet. 81: 661-667.

KNIGHT, M.R. 1992. Using transgenic plants to investigate plant physiology and development. AgBiotech News and Inform. 4: 73-76.

Kochert, G., Halward, T., Branch, W.D. \& Simpson, C.E. 1991. RFLP variability in peanut (Arachis hypo- gaea L.) cultivars and wild species. Theor. Appl. Genet. 81: 565-570.

Köhler, F., Cardon, G., Pohlman, M., Gill, R. \& SCHIEDER, O. 1989. Enhancement of transformation rates in higher plants by low-dose irradiation: are DNA repair system involved in the incorporation of exogenous DNA into the plant genome. Plant Mol. Biol. 12: 189199.

-, Benediktsson, I., Cardon, G., Andreo, C.S. \& SCHIEDER, O. 1990. Effects of various irradiation treatments of plant protoplasts on the transformation rates after direct gene transfer. Theor. Appl. Genet. 79: 679685.

KOMARI, T. 1990. Genetic characterization of a doubleflowered tobacco plant obtained in a transformation experiment. Theor. Appl. Genet. 80: 167-171.

KRAWETZ, S.A. 1989. The polymerase chain reaction: opportunities for agriculture. AgBiotech. News and Inform. 1: 897-902.

Krol, VAN DER A.R., Mur, L.A., DE LANGe, P., Mol, J.N.M. \& SUITJE, A.R. 1990. Inhibition of flower pigmentation by antisense CHS genes: promoter and minimal sequence requirements for the antisense effect. Plant Mol. Biol. 14: 457-466.

KuMAR, V.K. \& SPENCER, M.E. 1992. Nucleotide sequence of an osmotin cDNA from the Nicotiana tabacum cv. White Burley generated by the polymerase chain reaction. Plant Mol. Biol. 18: 621-622.

KURKelA, S. \& FranCK, M. 1990. Cloning and characterization of a cold-and ABA-inducible Arabidopsis gene. Plant Mol. Biol. 15: 137-144.

LANDRY, B.S., Kesseli, R.V., FarRara, B. \& Michelmore, R.W. 1987. A genetic map of lettuce (Lactuca sativa L.) with restriction fragment length polymorphism, isozyme, disease resistance and morphological markers. Genetics 116: 331-337.

Logemann, J., Jach, G., Tommerup, H., Mundy, J. \& SCHELL, J. 1992. Expression of a barley ribosomeinactivating protein leads to increased fungal protection in transgenic tobacco plants. Biotech. 10: 305-308.

Lonsdale, D., Onde, S. \& Cuming, A. 1990. Transient expression of exogenous DNA in intact, viable wheat embryos following particle bombardment. J. Expt. Bot. 41: 1161-1165.

MaAs, C., Laufs, J., Grant, S., Korfhage, C. \& Werr, W. 1991. The combination of a novel stimulatory element in the first exon of the maize shrunken-1 gene with the following intron 1 enhances reporter gene expression up to 1000 fold. Plant Mol. Biol. 16: 199-208.

Mariani, C., De Beuckeleer, M., Truettner, J., Leemans, J. \& GOLDBERG, R.B. 1990. Induction of male sterility in plants by a chimeric ribonuclease gene. Nature 347: 737741.

Mathews, H., Bharathan, N., Litz, R.E., Narayanan, K.R., RAO, P.S. \& BHATIA, C.R. 1990. The promotion of Agrobacterium mediated transformation in Atropa bella- 
dona L. by acetosyringone. J. Plant Physiol. 136: 404409.

McCouch, S.R., Kochert, G., Yu, Z.H., Wang, Z.Y., Khush, G.S., Coffman, W.R. \& TanKsley, S.D. 1988. Molecular mapping of rice chromosomes. Theor. Appl. Genet. 76: 815-829.

MELCHINGER, A.E. 1990. Use of molecular markers in breeding for oligogenic disease resistance. Plant Breed. 104: 1-19.

Mendel, R.R., Muller, B., Schulze, J., Kolesnikov, V. \& ZELENIN, A. 1989. Delivery of foreign genes to intact barley cells by high-velocity microprojectiles. Theor. Appl. Genet. 78: 31-34.

Messeguer, R., Ganal, M., De Vicente, M.C., Young, N.D., BolKan, H. \& TANKSLEY, S.D. 1991. High resolution RFLP map around the root knot nematode resistance gene (Mi) in tomato. Theor. Appl. Genet. 82: 529-536.

Meyer, P., Walgenbach, E., Bussmann, K., Hombrecher, G. \& SAEDler, H. 1985. Synchronized tobacco protoplasts are efficiently transformed by DNA. Mol. Gen. Genet. 201: 513-518.

Mishra, K.P., JoshuA, D.C. \& BhatiA, C.R. 1987. In vitro electroporation of tobacco pollen. Plant Sci. 52: 135139.

Mooney, P.A., Goodwin, P.B., Dennis, E.S. \& Llewellyn, D.J. 1991. Agrobacterium tumefaciens -gene transfer into wheat tissues. Plant Cell, Tiss. \& Org. Cult. 25: 209218.

Muller, E., Brown, P.T.H., Hartke, S. \& Lörz, H. 1990. RFLP- analysis of rice plants regenerated from tissue cultures. In: Nijkamp et al. (eds). Progress in Plant Cellular and Molecular Biology. Kluwer Acad. Pub., Dordrecht, The Netherlands, p. 153-156.

Namba, S., Ling, K., Gonsalves, C., Gonsalves, D. \& SLIGHTOM, J.L. 1991. Expression of the gene coding the coat protein of cucumber mosaic virus (CMV) strain WL appears to provide protection to tobacco plants against infection by several different CMV strains. Gene 107: 181-188.

Neale, D.B. \& Williams, C.G. 1991. Restriction fragment length polymorphism mapping in conifers and applications to forest genetics and tree improvement. Can. J. For. Res. 21: 545-554.

Newton, R.J., Yibrah, H.S., Dong, N., Clapham, D.H. \& VON ARNOLD, S. 1992. Expression of an abscisic acid responsive promoter in Picea abies (L.) Karst. following bombardment from an electric discharge particle accelarator. Plant Cell Rept. (in press).

Nienhuis, J., Helentuaris, T., Slocum, M., Ruggero, B. \& SCHAEFER, A. 1987. Restriction fragment length polymorphism analysis of loci associated with insect resistance in tomato. Crop Sci. 27: 797-803.

Nүвом, H. 1990. Genetic variation in ornamental apple trees and their seedlings (Malus, Rosaceae) revealed by DNA "fingerprinting". Hereditas 113: 17-28.

-, Rogstad, S.H. \& SCHAAL, B.A. 1990. Genetic variation detected by use of the M13 "DNA fingerprint" probe in Malus, Prumus and Rubus (Rosaceae). Theor. Appl. Genet. 79: 153-156.

— \&SCHAAL, B.A. 1990. DNA "fingerprints" applied to paternity analysis in apples (Malus $\mathrm{x}$ domestica). Theor. Appl. Genet. 79: 763-768.

Osborn, T.D., AleXAnder, D.C. \& Fobes, J.F. 1987. Identification of restriction fragment length polymorphisms linked to genes controlling soluble solid content in tomato fruit. Theor. Appl. Genet. 73: 350-356.

PARAN, I., KesSEli, R. \& MicelmoRe, R.W. 1991. Identification of restriction fragment length polymorphism and random amplified polymorphic DNA markers linked to downey mildew resistance genes in lettuce, using nearisogenic lines. Genome 34: 1021-1027.

Pen, J., MolendiJK, L., Quax, W.J., SiJmons, P.C., van OOyen, A.J.J., VAn den Elzen, P.J.M., Rietveld, K. \& HoEkemA, A. 1992. Production of active Bacillus licheniformis alpha-amylase in tobacco and its applications in starch liquefaction. Biotech. 10: 292-296.

Perlak, F.J., Deaton, R.W., Armstrong, T.A., Fuchs, R.L., Sims, S.R., Greenplate, J.T. \& FischHofF, D.A. 1990. Insect resistant cotton plants. Biotech. 8: 939-943.

PoTRYKuS, I. 1991. Gene transfer to plants: Assessment of published approaches and results. Ann. Rev. Pl. Physiol. Pl. Mol. Biol. 42: 205-225.

Powell, P.A., Nelson, R.S., De, B., Hoffman, N., Rogers, S.G., Fraley, R.T. \& BEAChY, R.N. 1986. Delay of disease development in transgenic plants that express the tobacco mosaic virus coat protein gene. Sci. 232: 738743.

-, Sanders, P.R., Tumer, N., Fraley, R.T. \& Beachy, R.N. 1990. Protection against tobacco mosaic virus infection in transgenic plants requires accumulation of coat protein rather than coat protein RNA sequences. Virology 175: 124-130.

-, Stark, D.M., Sanders, P.R. \& Beachy, R.N. 1989. Protection against tobacco mosaic virus in transgenic plants that express tobacco mosaic virus antisense RNA. Proc. Natl. Acad. Sci. USA. 86: 6949-6952.

Powell, W., Phillips, M.S., McNicol, J.W. \& WAUgh, R. 1991. The use of DNA markers to estimate the extent and nature of genetic variability in Solanum tuberosum cultivars. Ann. appl. Biol. 118: 423-432.

Quick, W.P., SchurR, U., ScheIBE, E.D., Rodermel, S.R., Bogorad, L. \& STITT, M. 1991. Decreased ribulose-1,5bisphosphate carboxylase-oxygenase in transgenic tobacco transformed with "antisense" rbcS. I. Impact on photosynthesis in ambient growth conditions. Planta 183: 542-554.

Quiros, C.F., Hu, J., This, P., Chevre, A.M. \& Delseny, M. 1991. Development and chromosomal localization of genome- specific markers by polymerase chain reaction in Brassica. Theor. Appl. Genet. 82: 627-632.

Rafalski, J.A., Tingey, S.V. \& Williams, G.K. 1991. RAPD markers - a new technology for genetic mapping 
and plant breeding. AgBiotech News and Inform. 3: 645648.

Raineri, D.M., Bottino, P., Gordon, M.P. \& Nester, E.W. 1990. Agrobacterium-mediated transformation of rice (Oryza sativa L.) Biotech. 8: 33-38.

Reiter, R.S., CoOrS, J.G., SusSman, M.R. \& Gabelman, W.H. 1991. Genetic analysis of tolerance to lowphosphorous stress in maize using restriction fragment length polymorphisms. Theor. Appl. Genet. 82: 561568 .

Robert, L.S., Donaldson, P.A., Ladaique, C., Altosaar, I., ARnison, P.G. \& Fabijanski, S.F. 1990. Antisense RNA inhibition of B-glucuronidase gene expression in transgenic tobacco can be transiently overcome using a heat-inducible B-glucuronidase gene construct. Biotech. 8: 459-464.

RodenberG, K.W., De Groot, M.J.A., Schilperoort, R.A. \& HoOYKaAs, P.J.J. 1989. Single-stranded DNA used as an efficient new vehicle for transformation of plant protoplasts. Plant Mol. Biol. 13: 711-719.

RosentHAL, A. 1992. PCR amplification techniques for chromosome walking. Trends in Biotech. 10: 44-47.

Rothstein, S.J., DiMaio, J., Strand, M. \& Rice, D. 1987. Stable and heritable inhibition of the expression of nopaline synthase in tobacco expressing antisense RNA. Proc. Natl. Acad. Sci. USA. 84: 8439-8443.

Saiki, R.K., Scharf, S., Faloona, F., Mullis, K.B., Horn, G.T., ERlich, H.A. \& ARnheim, A. 1985. Enzymatic amplification of B-globin genomic sequences and restriction site analysis for diagnosis of sickle cell anemia. Sci. 230: 1350-1354.

Sandler, S.J., Stayton, M., Townsend, J.A., Ralston, M.L., BEDBROOK, J.R. \& DUNSMUIR, P. 1988. Inhibition of gene expression in transformed plants by antisense RNA. Plant Mol. Biol. 11: 301-310.

SANFORD, J. 1990. Bioloistic plant transformation - a critical assessment. Physiol Plant 79: 206-209.

- 1992. The biolistic process: A simple tool for transforming diverse crop species. In: Whelan et al. (eds.). Advances in Gene Technology: Feeding the World in the 21 st Century. p. 4.

Sangwan, R.S. \& Sangwan-Norreel, B.S. 1990. Genetic transformation and plant improvement. In: Sangwan \& Sangwan-Norreel (eds.). The Impact of Biotechnology in Agriculture. Kluwer Academic Publishers, Dordrecht, The Netherlands, p. 299-337.

Sarfatti, M., AbU-Abied, M., Katan, J. \& Zamir, D. 1991. RFLP mapping of 11 , a new locus in tomato conferring resistance against Fusarium oxysporum f. sp. lycopersici race 1. Theor. Appl. Genet. 82: 22-26.

Sautter, C., Waldner, H., Neuhaus-Url, G., Galli, A., Neuhaus, G. \& Potrykus, I. 1991. Micro-targeting: High efficiency gene transfer using a novel approach for the accelaration of micro-projectiles. Biotech. 9: 10801085.

SChĀFer, W., GoRZ, A. \& KAHL, G. 1987. T-DNA integra- tion and expression in a monocot crop plant after induction of Agrobacterium. Nature 327: 529-531.

SCHLÄPPI, M. \& HoHN, B. 1992. Competence of immature maize embryos for Agrobacterium-mediated gene transfer. The Plant Cell 4: 7-16.

Senaratna, T., McKersie, B.D., Kasha, K.J. \& ProcuNIER, J.D. 1991. Direct DNA uptake during the imbibition of dry cells. Plant Sci. 79: 223-228.

Sengupta-Gopalan, C., Reichert, N.A., Barker, R.F., HALL, T.C. \& KeMP, J.D. 1985. Developmentally regulated expression of phaseolin, a bean protein gene, in tobacco seeds. Proc. Natl. Acad. Sci. USA. 82: 33203324.

Serres, R., Stang, E., McCabe, D., Russell, D., Mahr, D. \& McCown, B. 1992. Gene transfer using electric discharge particle bombardment and recovery of transformed cranberry plants. J. Amer. Soc. Hort. Sci. 117: 174-180.

Shah, D.M., Horsch, R.B., Kıee, H.J., Kishore, G.M., Winter, J.A., Tumer, N.E., Hironaka, C.M., SANDERs, P.R., Gasser, C.S., AyKent, S., Siegel, N.R., RogERS, S.R. \& FRALEY, R.T. 1986. Engineering herbicide tolerance in transgenic plants. Sci. 233: 478-481.

Sheikholeslam, S.N. \& WeEks, D.P. 1987. Acetosyringone promotes high efficiency transformation of Arabidopsis thaliana explants by Agrobacterium tumefaciens. Plant Mol. Biol. 8: 291-298.

Sijmons, P.C., Dekker, B.M.M., Schrammeijer, B., Verwoerd, T.C., van den Elzen, P.J.M. \& Hoekema, A. 1990. Production of correctly processed human serum albumin in transgenic plants. Biotech. 8: 217-221.

SLIGHтом, J.L. 1991. Custom polymerase-chain-reaction engineering of a plant expression vector. Gene 100: 251255 .

SMIGOCKI, A.C. \& Owens, L.D. 1989. Cytokinin gene fused with a strong promoter enhances shoot organogenesis and zeatin levels in transformed plant cells. Proc. Natl. Acad. Sci. USA. 85: 5131-5135.

SMIth, C.J.S., WATSON, C.F, RAY, J., BIRD, C.R., MorRIS, P.C., Schuch, W. \& Grierson, D. 1988. Antisense RNA inhibition of polygalacturonase gene expression in transgenic tomatoes. Nature 334: 724-726.

-, Watson, C.F., Morris, P.C., Bird, C.R., Seymour, G.B., Gray, J.E., Arnold, C., Tucker, G.A., Schuch, W., HARDING, S. \& GrIERSON, D. 1990. Inheritance and effect on ripening of antisense polygalacturonase genes in transgenic tomatoes. Plant Mol. Biol. 14: 369-379.

Stalker, D.M., McBride, K.E. \& Malyj, L.D. 1988. Herbicide resistance in transgenic plants expressing a bacterial detoxification gene. Sci. 242: 419-423.

Stewart, L.M.D., Hirst, M., Ferber, M.L., Merryweather, A.T., Cayley, P.J. \& Possee, R.D. 1991. Construction of an improved baculovirus insecticide containing an insect-specific toxin gene. Nature 352: $85-$ 88.

StITt, M., Quick, W.P., SchurR, U., Schulze, E.D., Roder- 
MEL, S.R. \& Bogorad, L. 1991. Decreased ribulose-1,5bisphospahate carboxylase-oxygenase in transgenic tobacco transformed with "antisense" rbcS. II. Fluxcontrol coefficients for photosynthesis in varying light, $\mathrm{CO} 2$, and air humidity. Planta 183: 555-566.

Stomp, A.M., Weissinger, A. \& SEDEROFF, R.R. 1991. Transient expression from microprojectile-mediated DNA transfer in Pinus taeda. Plant Cell Rept. 10: 187 190.

Streber, W.R. \& Willmitzer, L. 1989. Transgenic tobacco plants expressing a bacterial detoxifying enzyme are resistant to 2,4-D. Biotech. 7: 811-816.

Svab, Z., HaJdukiewicz, P. \& Maliga, P. 1990. Stable transformation of plastids in higher plants. Proc. Natl. Acad. Sci. USA. 87: 8526-8530.

Tanksley, S.D., Young, N.D., Paterson, A.H. \& BonierBALE, M.W. 1989. RFLP mapping in plant breeding: new tools for an old Science. Biotech. 7: 257-264.

TOMALSKI, M.D. \& MiLLER, L.K. 1991. Insect paralysis by baculo-virus-mediated expression of a mite neurotoxin gene. Nature 352: 82-85.

Tyagi, S., Spörlein, B., Tyagi, A.K., Herrmann, R.G. \& KOOP, H.U. 1989. PEG-and electroporation-induced transformation in Nicotiana tabacum: influence of genotype on transformation frequencies. Theor. Appl. Genet. 78: 287-292.

Tzuri, G., Hillel, J., Lavi, U., Haberfeld, A. \& VaINSTEIN, A. 1991. DNA fingerprint analysis of ornamental plants. Plant Sci. 76: 91-97.

UChimiYa, H., HandA, T. \& BRAR, D.S. 1989. Transgenic plants. J. Biotechnol. 12: 1-20.

Vaeck, M., Keynaerts, A., Hofte, H., Jansens, S.,De Beuckelar, M., Dean, C., Zabean, M., van Montagu, M. \& Leemans, J. 1987. Transgenic plants protected from insect attack. Nature 328: 33-37.

VANDEKERCKHOVE, J., VAN DAMME, J., VAN LUSEBETTENS, M., Botterman, J., De Block, M., Vandewiele, M., De ClercQ, A., Leemans, J., Van Montagu, M. \& KrebBERS, E. 1989. Enkephalins produced in transgenic plants using modified $2 \mathrm{~S}$ seed storage proteins. Biotech. 7: 929-932.

VAN Lusebettens, M., VANDERhaeghen, R. \& VAN MonTAGU, M. 1991. Insertional mutagenesis in Arabidopsis thaliana: isolation of a T-DNA-linked mutation that alters leaf morphology. Theor. Appl. Genet. 81: 277284.

Vahala, T., Eriksson, T. \& Engström, P. 1991. Genetic variability in basket willow (Salix viminalis) detected by hybridization to a bacteriophage M13 DNA probe. Hereditas 115: 153-161.

Vasil, V., Brown, S.M., Re, D., Fromm, M.E. \& Vasil, I.K. 1991. Stably transformed callus lines from microprojectile bombardment of cell suspension cultures of wheat. Biotech. 9: 743-747.

Venkateswarlu, K. \& NaZar, R.N. 1991. Evidence for TDNA mediated gene targeting to tobacco chloroplasts.
Biotech. 9: 1103-1105

Walters, D.A., Vetsch, C.S., Potts, D.E. \& Lundquist, R.C. 1992. Transformation and inheritance of a hygromycin phosphotransferase gene in maize plants. Plant Mol. Biol. 18: 189-200.

WANG, C.Y., Hughes, K.W. \& HuANG, H. 1986. Improved cytoplasmatic delivery to plant protoplasts via $\mathrm{pH}$ sensitive liposomes. Plant Physiol. 82: 179-184.

Wang, M.L., Atkinson, M.D., Chinoy, C.N., Devos, K.M., Harcourt, R.L., LiU, C.J., Rogers, W.J. \& Gale, M.D. 1991. RFLP-based genetic map of rye (Secale cereale L.) chromosome 1R. Theor. Appl. Genet. 82: 174-178.

Weber, G., Monajembashi, S., Greulich, K.O. \& WolFRUM, J. 1989. Uptake of DNA in chloroplasts of Brassica napus (L.) facilitated by a UV-laser microbeam. Euro. J. Cell Biol. 49: 73-79.

Weising, K. \& KAHL, G. 1990. DNA fingerprinting in plants-the potential of the new method. Biotech. Forum Eur. 7: 230-235.

Wilde, H.D., Meagher, R.B. \& Merkle, S.A. 1992. Expression of foreign genes in transgenic yellow-poplar plants. Plant Physiol. 98: 114-120.

Williams, J.G.K., KubeliK, A.R., LiVAK, J., Rafalski J.A. \& TingeY S.V. 1990. DNA polymorphisms amplified by arbitrary primers are useful as genetic markers. Nucleic Acids Res. 18: 6531-6535.

Wu, K.K., Burnquist, W., Sorrells, M.E., Tew, T.L., MOORE, P.H. \& TANKSLEY, S.D. 1992. The detection and estimation of linkage in polyploids using single-dose restriction fragments. Theor. Appl. Genet. 83: 294-300.

Xu, Y.S., Clark, M.S. \& Pehu, E. 1992. Use of RAPD markers to screen somatic hybrids between Solanum tuberosum and $S$. brevidens. Plant Cell Rept. (in press).

Ye, G.N., DANIELl, H. \& SANFORD, J.C. 1990. Optimization of delivery of foreign DNA into higher-plant chloroplasts. Plant Mol. Biol. 15: 809-819.

YU, Z.H., MaCkill, D.J., Bonman, J.M. \& TANKSLEY, S.D. 1991. Tagging genes for blast resistance in rice vis linkage to RFLP markers. Theor. Appl. Genet. 81: 471-476.

Zhang, L.J., Cheng, L.M., Xu, N., ZhaO, N.M., Li, C.G., YUAN, J. \& JIA, S.R. 1991. Efficient transformation of tobacco by ultrasonication. Biotech. 9: 996-997.

Zhu, Z., Woodbury-Hughes, K. \& Huang, L. 1990. Transformation of tobacco protoplasts with DNA entraped in pH-sensitive liposomes. Plant Cell, Tiss. \& Org. Cult. 22: 135-145. 


\title{
S. Mohan Jain
}

Eija Pehu

University of Helsinki

Department of Plant Production

SF-00710 Helsinki, Finland

C Oker-Blom

Ảbo Akademi University

Department of Biochemistry and Pharmacy

SF-20520 Turku, Finland

\section{R J Newton \\ Texas A \& M University}

Department of Forest Science

College Station, Texas, USA

\section{SELOSTUS}

\section{Geenien muuntelu, lisäkeino kasvinparannukseen}

\author{
S. Mohan Jain, Christian Oker-Blom, Eija Pehu ja R.J. Newton \\ Helsingin yliopisto, Ảbo Akademi ja Texas A \& M University
}

Geeninsiirtoteknologiassa tapahtunut edistys on tehnyt mahdolliseksi yksi- ja kaksisirkkaisten siirtogeenisten kasvien tuotannon. Biolistisella menetelmällă voidaan siirtäă geenejä vaikeasti käsiteltäviin viljelykasveihin ja metsăpuihin riippumatta niiden genotyypistä. Pysyvää ja lyhytaikaista geenien siirtoa varten on kehitetty halvempia menetelmiä: ultraäänimetodi, suora DNA-siirto liotusvaiheessa kăyttåen kuivia somaattisia alkioita ja silikoni karbiidikuidut. Agrobacterium -vălitteistä kloonattujen geenien siirtoa kasvisoluihin voidaan tehostaa. Molekyylimerkkien - RFLP't, RAPD't ja DNA-sormenjälki - analysointi voi täydentäă viljelykasvien kuvailua, geenikartoitusta ja tunnistamista, takuutodistuksen antoa sekä patenttien suojaamista. PCR:n avulla voidaan valikoidusti monistaa spesifinen DNA-segmentti ottamalla vain pieni määrä organismin koko DNA:sta ja tunnistaa siirtogeeninen viljelykasvi. Kohteena olevan geenin toiminta voidaan estää antisense RNA'lla.

Toistaiseksi geeniteknologian avulla on tunnistettu ja kloonattu rajoitettu măărä geenejä. Spesifillă geeninsiirrolla päăstään moniin päämääriin: tuhohyönteisten ja sienien biologiseen torjuntaan, koiras-steriiliyteen, viruskestävyyteen, siemenproteiinien parantamiseen ja siirtogeenisten kasvien käyttöön bioreaktoreina. T-DNA mutageneesin avulla voidaan saada tietoa kasvin kehityksen ja morfogeneesin geneettisestä säătelystă sekă eristää hyödyllisiă mutantteja.

Ennen kuin geeniteknologia voi olla luotettava keino jalostaa kasveja, olisi kiinnitettävä enemmän huomiota kasvien geneettisten varojen selvittämiseen, jotta voitaisiin löytäă ja kloonata uusia geenejä. Samoin olisi selvitettävä selektiivisten ja raportoivien merkkigeenien vaikutuksia kasveissa ja tutkittava kenttäoloissa siirtogeenejä ja siirtogeenisiä kasveja. 